\title{
Edge effects and landscape matrix use by a small mammal community in fragments of semideciduous submontane forest in Mato Grosso, Brazil
}

\author{
Santos-Filho, M. ${ }^{\mathrm{a}, \mathrm{b} *}$, da Silva, DJ. ${ }^{\mathrm{a}, \mathrm{b} *}$ and Sanaiotti, $T M .^{\mathrm{a} *}$ \\ anstituto Nacional de Pesquisa da Amazônia - INPA, \\ Av. André Araújo, 2936, Aleixo, CEP 69060-001, Manaus, AM, Brazil \\ bUniversidade do Estado de Mato Grosso - UNEMAT, \\ Rua São Pedro, s/n, Cavalhada, CEP 78200-000, Cáceres, MT, Brazil \\ *e-mail: msantosfilho@gmail.com, dioneijs@unemat.br, sanaiott@inpa.gov.br \\ Received August 17, 2006 - Accepted June 26, 2007 - Distributed November 30, 2008
}

(With 2 figures)

\begin{abstract}
A community of small mammals was studied in seasonal semideciduous submontane forest in the state of Mato Grosso, Brazil. This study evaluated the use of edge and matrix pasture, by different small mammal species. Overall, 31 areas were studied, with a total sampling effort of 33,800 trap x nights. Only seven of the 25 species captured in the study sites were able to use the pasture matrix; we classified these species as generalists. Fourteen species were found to be intermediate in habits, being able to use forest edges. We found only four species habitat specialists, occurring only on transect lines in the interior of the fragment, at least $150 \mathrm{~m}$ from the edge. Transects located in the pasture matrix and $50 \mathrm{~m}$ from the edge had significantly lower species richness and abundance than transects located in the fragment edge or in the interior of the fragment. All transects located within the fragment had similar species richness and abundance, but transects located $50 \mathrm{~m}$ from the edge had slightly lower, but non-significant, species richness than transects located $100 \mathrm{~m}$ apart from edges. Rarefaction curves demonstrated that only medium-sized fragments (100-300 ha) reached an asymptote of species accumulation. The other areas require further sampling, or more sampling transect, before species accumulation curves stabilize, due to a continued increase in species number.
\end{abstract}

Keywords: edge effects, matrix of pasture, small mammals, forest fragments, Mato Grosso.

\section{Efeitos de borda e uso da matriz por uma comunidade de pequenos mamíferos em fragmentos de floresta semidecidual submontana no Mato Grosso, Brasil}

\begin{abstract}
Resumo
Uma comunidade de pequenos mamíferos foi estudada em fragmentos de floresta estacional semidecidual submontana no Estado de Mato Grosso, Brasil. Nesse estudo, buscou-se avaliar o uso da borda e da matriz de pastagem pelas diferentes espécies. No total, 31 áreas foram estudadas, com um esforço total de 33.800 armadilhas $\mathbf{X}$ noite. Apenas sete das 25 espécies capturadas foram capazes de utilizar a matriz de pastagem, sendo estas consideradas generalistas. Quatorze foram consideradas intermediárias no uso do habitat, sendo capazes de utilizar habitats de borda. Encontramos apenas quatro especialistas, ocorrendo somente nas transecções do interior do fragmento, a aproximadamente $150 \mathrm{~m}$ da borda. Dentre todas as transecções utilizadas para amostragem, a disposta na matriz de pastagem, a $50 \mathrm{~m}$ da borda, demonstrou ser significativamente menos rica e abundante que as dispostas na borda e no interior dos fragmentos. Todas as transecções localizadas dentro do fragmento tiveram riqueza e abundância de espécies similares, porém a transecção localizada a $50 \mathrm{~m}$ da borda teve uma tendência a ser menos rica que a transecção a $100 \mathrm{~m}$. Através de ajustes das curvas de rarefação, somente uma das áreas considerada de médio porte, entre 100 a 300 ha., atingiu uma assíntota. As outras áreas necessitam de um maior número de transecções, a fim de se obter uma estabilização das curvas, pois continuaram a acrescentar espécies.
\end{abstract}

Palavras-chave: efeito de borda, matriz de pastagem, pequenos mamíferos, fragmentos florestais, Mato Grosso. 


\section{Introduction}

Anthropogenic influences are affecting larger and larger blocks of continuous forest, reducing them to fragments in a sea of pasture or other secondary habitat (Malcolm, 1997). The fragments left standing suffer drastic changes caused by edge effects (Andrews, 1990; Laurance et al. 1997; Laurance, 2001). Other factors, such as low humidity, high temperatures, and dry wind from the landscape matrix, cause tree mortality and accumulation of leaves along edges (Lovejoy, 1985; Stevens and Husband, 1998; Laurance et al. 2002), increasing a fragment's susceptibility to fire (Laurance et al. 2002). The scale of the fragmentation effects depend upon the quality of the matrix in which the fragment resides (Laurance and Delamônica, 1998; Mesquita et al., 1999), since the matrix determines the conditions to which the fragment is exposed (Stevens and Husband, 1998). For example, fragmentation effects are usually reduced when the matrix has a structure similar to that of adjacent forest, since many forest species are then able to use the matrix as an alternative habitat or corridor (Laurance, 1990; 1991; 1994; Malcom, 1991; Stouffer and Bierregaard, 1995; Gascon et al., 1999; Laurance et al. 2002). In some cases high quality matrix is of such importance to the animal community that it minimizes the effects of fragment size and isolation (Rodewald, 2003).

Passamani (2003) and Pardini (2004), studying fragments in the Atlantic Forest, found that small mammal species richness and abundance is similar among fragments found in matrixes of coffee plantations, secondary vegetation, and shade cocoa plantations.

The results of Pardini (2004), in Atlantic Forest fragments, indicate that only arboreal species are affected by edge effects. While some species are negatively affected, others benefit from this change and increase in abundance (Figueiredo and Fernandez, 2004; Malcolm, 1997). In Brazil, the capacity of small mammal communities to occupy altered areas was studied in forest areas by Malcolm (1991; 1995); Fernandez et al. (1998); Stallings (1989) and Rittl (1998).

Although those studies already indicated edge effects for several types of matrixes, the pasture matrix is one of the most unused. In the study region only forest fragments remain regarding from the original continuous forest. To understand the ecology of those species that inhabit those areas is of crucial importance for conservation.

The objective of the present study is to evaluate edge effects and matrix use by the small mammal community in areas of seasonal semideciduous forest in southwestern Mato Grosso.

\section{Materials and Methods}

\subsection{Study area}

We sampled the small mammal communities of 22 sites located in the microbasins of the Jauru and
Cabaçal Rivers, tributaries of the Paraguay River, in southwest Mato Grosso, Brazil. Our study sites were located between $15^{\circ} 15^{\prime} 06^{\prime \prime} \mathrm{S}$ and $58^{\circ} 42^{\prime} 56^{\prime \prime} \mathrm{W}$ and $15^{\circ} 33^{\prime} 43^{\prime \prime} \mathrm{S}$ and $58^{\circ} 00^{\prime} 17^{\prime \prime} \mathrm{W}$ in the municipalities of Figueirópolis D'Oeste; Indiavaí, Araputanga, IV Marcos, Mirassol D'Oeste, Curvelândia, Lambari D'Oeste, and Rio Branco (Figure 1). Three of our 22 study sites were located in continuous forest (larger than 1,000 ha) and 19 were located in forest fragments ranging from 41 to 468 ha.

\subsection{Vegetation}

The vegetation of the study area is similar to that of Amazonian forest, but is not considered part of the dominant Amazonian morphoclimate (MCT/CNPq, 1985). Detailed descriptions of the local vegetation characterize the forest in the region as Seasonal Submontane Semideciduous Forest (see Amaral and Fonzar, 1982; HABTEC, 2001; and SEPLAN, 2004). This vegetation type occurs in locations where elevation varies from 100-500 m. Eutrophic Red Yellow Podzolic soils predominate in the study area (Oliveira et al., 1982). The climate of the region follows the climate classification aw of Köppen. Mean annual precipitation in the region is $1,330 \mathrm{~mm}$. High temperatures persist year-round, with a mean maximum temperature of $24.9^{\circ} \mathrm{C}$ for the months of December to January. A small temperature decline occurs in June and the minimum temperature (near $20^{\circ} \mathrm{C}$ occurs more often in July (Resende et al., 1994).

\section{Sampling Methods and Experimental Design}

\subsection{Conventional trap sampling using Sherman, Tomahawk, and snap traps}

We established a sampling system in each fragment consisting of eight parallel principal transect lines of about $135 \mathrm{~m}$ long (Figure 2), where we installed a repeated sequence of one Sherman $(80 \times 90 \times 230 \mathrm{~mm})$, one Tomahawk (145 x $145 \times 410 \mathrm{~mm})$, and one snap $(90 \times 150 \mathrm{~mm})$ traps. Parallel transects were always $50 \mathrm{~m}$ apart, except on the edge, where the distance between transect A (in the pasture matrix) and B (in edge habitat) was $60 \mathrm{~m}$ (see Figure 2). Each principal transect had 10 collecting points, spaced every $15 \mathrm{~m}$ apart, for a total of 80 traps per night in each fragment. At each collecting point in the fragments we set up one Sherman, Tomahawk or Snap trap, alternating one on the ground and other at a height of approximately $2 \mathrm{~m}$. Traps were baited with banana and peanut butter and were checked daily for a total of 10 consecutive nights. For the study, total capture effort was 24,800 conventional trap-nights.

\subsection{Pitfall trap sampling}

We installed six lines of pitfall traps in each study area, in the intervals between each one of the first six principal transects containing conventional traps (Figure 2). The first line was located in the pasture, $25 \mathrm{~m}$ from the forest fragment edge. The second was located 
on the edge and the other every $50 \mathrm{~m}$ apart into the forest, with the last $200 \mathrm{~m}$ from the edge (Figure 2). The distance between transects of conventional traps and pitfall traps was $25 \mathrm{~m}$, except at the edge, where it was $10 \mathrm{~m}$ (Figure 2). Each trap line was $50 \mathrm{~m}$ long and com- posed of five 23.6 L plastic barrels, spaced every $10 \mathrm{~m}$. Barrels were shaped like a truncated cone, with a height of $37 \mathrm{~cm}$, a $30 \mathrm{~cm}$ diameter mouth, and a $26 \mathrm{~cm}$ diameter floor. Barrels were buried to their rims in the ground and linked at ground level by an $80 \mathrm{~cm}$-high plastic guide

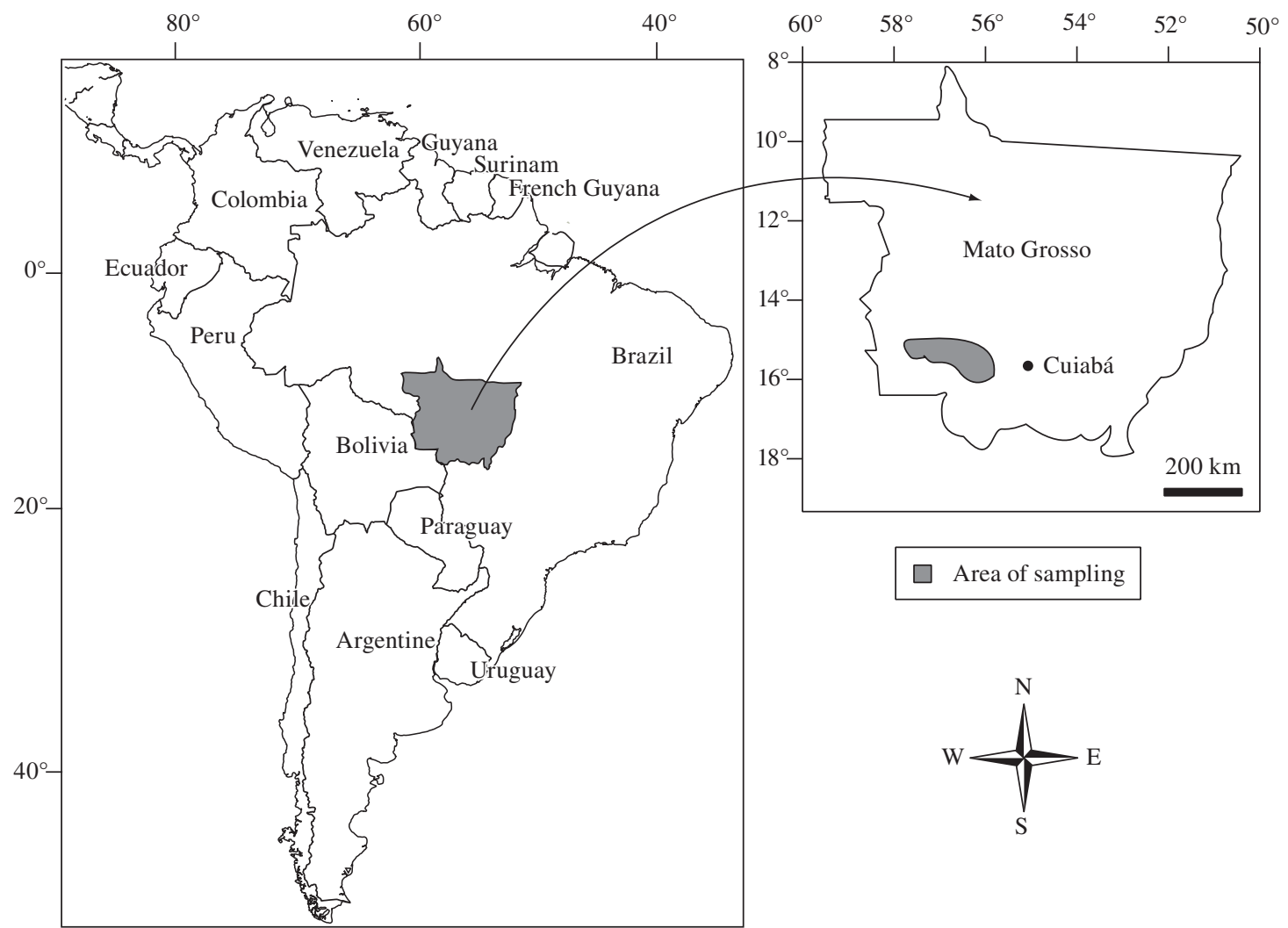

Figure 1. Map of the state of Mato Grosso. The area in brown indicates the study area.

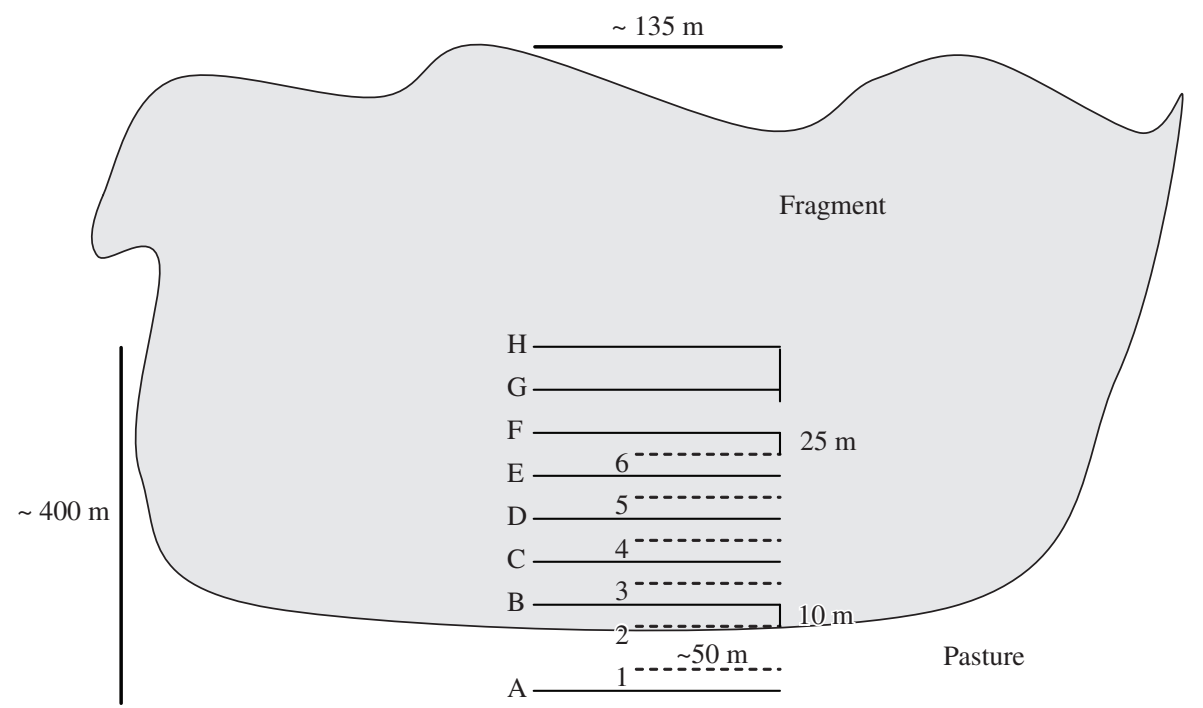

Figure 2. Schematic representation of transect lines within the forest fragments and in the pasture matrix. Solid lines represent transects Tomahawk, Sherman, and snap traps and dashed lines represent transect lines with pitfall traps. 
fence, attached by staples to wooden support stakes. The inferior edge of the guide fence was buried about $5 \mathrm{~cm}$ into the soil. During the rainy season, pieces of Styrofoam were placed in barrels, to avoid animals drowning, and barrels were periodically emptied of water. Pitfall traps were checked daily and remained open for 10 consecutive days, for a total of 9,000 barrel-nights over the entire study. The study was carried out between January and February during the rainy season, and between July and August during the dry season in the years 2003 and 2004. Three areas were sampled simultaneously for each 10 day period. All fragments studied had pasture as a matrix, being of pasture with different grazing pressures. To evaluate edge effects all individuals captured in the pitfall trap and conventional trap transects were considered to be captured in one unique transect. For example, transect "A" of conventional traps and transect " 1 " of pitfall traps were considered as just a sole transect in the analyses, and so on, successively, and with this, even transect B of conventional traps $10 \mathrm{~m}$ from the edge was considered distance zero.

Due to the inexistence of previous studies for the region, 20 specimens for each species, 10 males and $10 \mathrm{fe}-$ males, were collected to represent the region as voucher specimens. Since none of the fragments had more than 10 individuals of each species, studies of mark and recapture were not carried out.

Species were separated by their type of habitat use, depending upon where they were captured. According to the type of habitat used, species were classified as generalists, intermediates, and specialists.

Species that were captured in all transect lines from the pasture matrix to the interior of the fragment were considered generalists. Species that only used the edge and interior of the fragment were considered intermediates. Only those collected more than $100 \mathrm{~m}$ from the edge, in the fragments, were considered specialists.

\subsection{Statistical analysis}

Species richness and abundance of small mammals were evaluated using the non-parametric Wilcoxon Signed Ranks test, with Bonferroni correction. Differences were considered significant at the $\mathrm{P}$ level of 0.05 . We used absolute numbers for species richness and abundance comparisons.

\section{Results}

In this study, seven of the 25 species captured used the pasture matrix. Within the species considered as generalists (Table 1), only Calomys sp. and Oligoryzomys microtis did not use transect "H," $300 \mathrm{~m}$ from the edge. Calomys sp. was as abundant in the pasture matrix as in fragment interiors. The two Neacomys spinosus individuals captured in the pasture matrix were juveniles.

Fourteen species were considered intermediates, or those that occupied altered areas along edges as well as intact areas within the fragment. Marmosops noctivagus,
Micoureus demerarae, and Oryzomys megacephalus were not present in the pasture matrix, but had similar abundances in all transects within the fragment. These were the three most abundant species during the study, representing $61 \%$ of all captures (Table 1). Only one individual of Philander opossum was captured on the edge, but was still considered an intermediate, due to its ability to occupy altered areas. Metachirus nudicaudatus, Oryzomys nitidus, Proechimys gr. longicaudatus, Oecomys roberti, and Oecomys bicolor were less abundant, but had a homogeneous distribution among transects and were not captured in the matrix habitat. Oecomys sp., Monodelphis domestica, Mesomys hispidus, Akodon toba, and Rhipidomys mastacalis occurred in low densities in the study areas and used only up to transect "C," $50 \mathrm{~m}$ from the fragment edge. This species was never captured on the transect at the edge (Table 1).

Glironia venusta, Caluromys philander, Monodelphis brevicaudata, and Didelphis marsupialis were captured on transects at least $150 \mathrm{~m}$ from the edge and occurred in low densities; we considered these species specialists and susceptible to fragmentation (Table 1).

Across all study areas, the number of individuals captured on "A" transects, located in the pasture matrix, was significantly lower than numbers of captures along the edge and interior of the fragments (Wilcoxon Rank Test analysis, $\mathrm{P}<0.05$, Table 2 ). Transects within fragments did not significantly differ in small mammal abundances, only the transect $50 \mathrm{~m}$ from the edge tended to have lower species abundance than the transect $100 \mathrm{~m}$ from the edge (Wilcoxon Rank Test analysis, $\mathrm{P}=0.072$, Table 2).

All transects in the pasture matrix were significantly less species rich than transects along fragment edges or interiors, but we found no significant difference in species richness between edge and interior transects (Wilcoxon Rank Test, $\mathrm{P}<0.05$, Table 2).

\section{Discussion}

Of all the species present in the areas, only $28 \%$ used pasture habitat. Of these, only two species may be considered capable of living permanently in the matrix (Necromys lasiurus and Calomys sp.), because they were captured in large number in the pasture, edge and interior of the fragments. The other four species had low abundances in the matrix and the majority of the individuals captured there were juveniles, probably in dispersion period. Most species captured in the matrix during this study were rodents, while Passamani (2003) found that marsupials dominate in pasture habitats. From the four species captured in this study, two (Necromys lasiurus and Calomys sp.) are considered opportunists.

Most captures of Necromys lasiurus occurred in the pasture matrix, but we also recorded the species $300 \mathrm{~m}$ into the fragment. This species is considered to prefer open areas (Pires et al. 2002; Vieira and Marinho-Filho, 1998; Mares and Ernest, 1995; Mares et al. 1989; Vieira, 
Table 1. Small mammal species abundance in 22 study sites, recorded on transect lines in the pasture matrix "A" (Matrix), edge "B" (Edge), and every $50 \mathrm{~m}$ from edge to interior of fragment "C-H" (Fragment). Species were classified as specialists, intermediates, or generalists, according to their frequency of the matrix, edge, and interior of fragment habitat.

\begin{tabular}{|c|c|c|c|c|c|c|c|c|c|}
\hline \multirow[t]{2}{*}{ Species } & \multicolumn{9}{|c|}{ Transects } \\
\hline & $\mathbf{A}$ & B & C & D & $\mathbf{E}$ & $\mathbf{F}$ & G & $\mathbf{H}$ & \\
\hline Necromys lasiurus (Lund, 1841) & 17 & 4 & 1 & 0 & 0 & 1 & 1 & 2 & \\
\hline Calomys sp. & 7 & 10 & 3 & 4 & 10 & 4 & 0 & 0 & \\
\hline Marmosa murina (Linnaeus, 1758) & 2 & 4 & 3 & 6 & 4 & 3 & 4 & 4 & $\stackrel{0}{0}$ \\
\hline Gracilinanus agilis (Burmeister, 1854) & 2 & 5 & 4 & 8 & 1 & 8 & 3 & 3 & $\sqrt{0}$ \\
\hline Monodelphis adusta (Thomas, 1897) & 1 & 5 & 1 & 2 & 2 & 1 & 0 & 1 & $\overline{0}$ \\
\hline Neacomys spinosus (Thomas, 1882) & 2 & 0 & 8 & 4 & 2 & 6 & 3 & 1 & \\
\hline Oligoryzomys microtis (Allen, 1916) & 1 & 2 & 2 & 0 & 0 & 3 & 0 & 0 & \\
\hline Marmosops noctivagus (Tschudi, 1845) & 0 & 27 & 23 & 36 & 28 & 54 & 33 & 21 & \\
\hline Micoureus demerarae (Thomas, 1905) & 0 & 23 & 20 & 22 & 24 & 30 & 27 & 31 & \\
\hline Oryzomys megacephalus Fischer, 1814 & 0 & 11 & 12 & 24 & 14 & 24 & 17 & 12 & \\
\hline Oecomys bicolor (Tomes, 1860) & 0 & 6 & 5 & 10 & 6 & 5 & 6 & 16 & \\
\hline Oecomys roberti (Thomas, 1904) & 0 & 4 & 5 & 5 & 3 & 4 & 2 & 8 & \\
\hline Proechimys gr. longicaudatus & 0 & 2 & 1 & 4 & 1 & 3 & 6 & 4 & $\stackrel{\mathscr{v}}{=}$ \\
\hline Oryzomys nitidus (Thomas, 1884) & 0 & 1 & 1 & 0 & 3 & 0 & 3 & 2 & 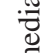 \\
\hline Metachirus nudicaudatus (E.Geoffroy, 1803) & 0 & 1 & 0 & 0 & 0 & 0 & 1 & 0 & $\overline{0}$ \\
\hline Philander opossum (Linnaeus,1758) & 0 & 1 & 0 & 0 & 0 & 0 & 0 & 0 & $\stackrel{\mathscr{U}}{\Xi}$ \\
\hline Oecomys sp. & 0 & 0 & 1 & 3 & 2 & 3 & 0 & 1 & \\
\hline Monodelphis domestica (Wagner, 1842) & 0 & 0 & 1 & 0 & 1 & 3 & 0 & 0 & \\
\hline Mesomys hispidus (Thomas, 1882) & 0 & 0 & 1 & 0 & 0 & 0 & 0 & 1 & \\
\hline Akodon toba Thomas, 1921 & 0 & 0 & 2 & 0 & 0 & 0 & 0 & 0 & \\
\hline Rhipidomys mastacalis (Lund, 1840) & 0 & 0 & 2 & 0 & 0 & 0 & 0 & 0 & \\
\hline Didelphis marsupialis Linnaeus, 1758 & 0 & 0 & 0 & 0 & 1 & 0 & 2 & 1 & $\frac{n}{0}$ \\
\hline Monodelphis brevicaudata (Erxleben,1777) & 0 & 0 & 0 & 0 & 0 & 1 & 0 & 2 & 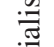 \\
\hline Caluromys philander (Linnaeus, 1758) & 0 & 0 & 0 & 0 & 0 & 1 & 0 & 0 & $\overline{\mathscr{D}}$ \\
\hline Glironia venusta Thomas, 1912 & 0 & 0 & 0 & 0 & 0 & 0 & 0 & 1 & \\
\hline
\end{tabular}

Table 2. Matrix of Wilcoxon Rank Test for total abundance and richness of small mammals for the transects in the 22 sites. -50 represents pasture matrix, zero the edge, and each $50 \mathrm{~m}$ interval towards the fragment center.

\begin{tabular}{ccccccccc}
\hline & \multicolumn{8}{c}{ Distance from the edge (m) } \\
\cline { 2 - 9 } & $\mathbf{- 5 0}$ & $\mathbf{0}$ & $\mathbf{5 0}$ & $\mathbf{1 0 0}$ & $\mathbf{1 5 0}$ & $\mathbf{2 0 0}$ & $\mathbf{2 5 0}$ & $\mathbf{3 0 0}$ \\
\hline Abundance & $\mathrm{Z}=0.000$ & $\mathrm{Z}=3.278$ & $\mathrm{Z}=3.003$ & $\mathrm{Z}=3.644$ & $\mathrm{Z}=3.404$ & $\mathrm{Z}=3.533$ & $\mathrm{Z}=3.045$ & $\mathrm{Z}=3.258$ \\
$\mathbf{- 5 0}$ & $\mathrm{P}=1.000$ & $\mathbf{P}=\mathbf{0 . 0 0 8}$ & $\mathrm{P}=0.024$ & $\mathbf{P}=\mathbf{0 . 0 0 1}$ & $\mathbf{P}=\mathbf{0 . 0 0 8}$ & $\mathbf{P}=\mathbf{0 . 0 0 1}$ & $\mathbf{P}=\mathbf{0 . 0 1 6}$ & $\mathbf{P}=\mathbf{0 . 0 0 8}$ \\
Richness & $\mathrm{Z}=0.001$ & $\mathrm{Z}=3.552$ & $\mathrm{Z}=3.564$ & $\mathrm{Z}=3.865$ & $\mathrm{Z}=3.750$ & $\mathrm{Z}=3.571$ & $\mathrm{Z}=3.413$ & $\mathrm{Z}=3.542$ \\
$-\mathbf{5 0}$ & $\mathrm{P}=1.000$ & $\mathbf{P}=\mathbf{0 . 0 0 1}$ & $\mathbf{P}=\mathbf{0 . 0 0 1}$ & $\mathbf{P}=\mathbf{0 . 0 0 1}$ & $\mathbf{P}=\mathbf{0 . 0 0 1}$ & $\mathbf{P}=\mathbf{0 . 0 0 1}$ & $\mathbf{P}=\mathbf{0 . 0 0 8}$ & $\mathbf{P}=\mathbf{0 . 0 0 1}$ \\
\hline
\end{tabular}

2002), but is sometimes encountered in forested areas (Magnusson et al., 1995; Santos-Filho, 2000).

Despite the low number of captures of Oligoryzomys microtis in this study, it is common to capture this genus in altered areas and open habitats (Stallings, 1989; Pardini, 2004; Pires et al., 2002).

Calomys sp. apparently does not have a preference for a specific type of habitat and we found it to be as common in the matrix as in the interior of the fragments. In the Cerrado, Calomys callosus is more of an opportunist than Necromys lasiurus. Necromys lasiurus experienced a decrease in population size after fire, while Calomys callosus populations increased (Vieira, 1999).

The two captures of Marmosa murina in the pasture occurred in areas with tall grass subjected to low grazing pressure. Grazing pressure most likely influenced matrix capture rates; we did not capture individuals in pasture with high grazing pressure. For arboreal species, areas without a substrate to climb constituted an even greater barrier. Pardini (2004), in Atlantic Forest, found two 
times more Marmosa murina along the edge than in the interior of the fragments. All sites studied had evidence of selective logging in low or high intensity, and the gaps created were frequently favored by opportunistic species such as Marmosa murina.

Despite the few captures of the species Gracilinanus agilis, Monodelphis adusta, and Neacomys spinosus in the pasture matrix, they had a very homogeneous distribution along all transects, indicating their capacity to use open areas, as well as forest areas, and being lesssusceptible to habitat fragmentation.

Marmosops noctivagus, Micoureus demerarae, and Oryzomys megacephalus were very abundant along the edge, as well as on other transects, and had a homogeneous distribution. In this study these species were considered as less vulnerable to edge effects, however these species were never captured in the matrix. In Atlantic Forest fragments, Pardini (2001) considered Marmosops incanus vulnerable to habitat fragmentation due to its greater abundance in the interior of the forest than at the edge. Passamani (2003) found a different pattern, with the same species being more abundant along edges, including being able to cross a coffee-plantation matrix and relocate almost a kilometre away.

Micoureus demerarae was the second-most abundant species in this study and was captured on all transects in the interior of the fragments, but never in the pasture. In Atlantic Forest fragments, Pires et al. (2002) found that $M$. demerarae males moved among fragments situated in a matrix of tall grass. In the Amazon, Malcolm (1991) found Marmosa cinerea (= Micoureus demerarae) to be a generalist capable of using and traveling through a pasture matrix, demonstrating with this its dispersal capacity. Oryzomys megacephalus was very abundant with similar numbers of individuals along the edge and interior of fragments, but was absent in the pasture. This seems not to be standard for the genus, as Malcolm (1997), in Amazonian tropical forest, found $O$. macconnelli to be more common in continuous forest than secondary and fragmented forests. Pardini (2004), studying Atlantic Forest fragments, concluded that the most commonlycaptured species, Oryzomys laticeps, decreased in abundance in edge areas. Apparently, species of the same genus respond differently to edge effects.

Despite capturing only one Philander opossum individual and two Metachirus nudicaudatus individuals, and being considered rare in this study, these species are able to use altered areas. Pires et al. (2002) found these species in the tall grass matrix around Atlantic Forest fragments.

For arboreal species like Oecomys sp., O. bicolor, and $O$. roberti, the matrix of pasture may function as a barrier to dispersal (see Pires et al. 2002). Although Oecomys is an arboreal genus, it is often captured on the ground, indicating on the ground movements perhaps in search of food and places with deeper litter layer that would offer better protection against predators.
We captured few Proechimys gr. longicaudatus individuals during our study. This genus is often found in the type of habitat typical of the study area with many clearings and edges (Stevens and Husband, 1998; Rittl, 1998). Despite Monodelphis domestica and Rhipidomys mastacalis not using fragment edges in this study, they are sometimes found in open areas, such as rocky outcrops in the Cerrado (Santos-Filho, 2000). They have also been noted to move through coffee plantation matrix between Atlantic Forest fragments (Passamani, 2003).

Mesomys hispidus and Monodelphis brevicaudata were very rare in this study, but, despite this, they were able to occupy a large variety of habitats, from primary to secondary forest elsewhere. Mesomys has been reported to occupy palm-thatch roofs of houses in rural areas surrounded by intact forest (Emmons and Feer, 1997). Mesomys hispidus was significantly more abundant in 10 ha fragments than in continuous forest and 1 ha fragments, and was never captured in pasture (Malcolm, 1991).

In the study area Akodon toba was very rare, with only two captures at $50 \mathrm{~m}$ from the edge of the fragment. However, in disturbed areas of Atlantic Forest, a close relative, Akodon cursor, was found to be an opportunistic species, capable of using and increasing its abundance in altered areas (Figueiredo and Fernandez, 2004).

Despite Didelphis marsupialis being captured only in the interior of the fragment, this genus is considered generalist, able to occupy various types of habitats, including urban areas (Cáceres and Monteiro-Filho, 1997; 1998; 2000; Graipel and Santos-Filho, 2006).

We can consider the species Caluromys philander as rare and vulnerable to fragmentation effects, since it was captured only once in the centre of the fragment. Malcolm (1997) found this species to be less abundant in fragments than in continuous forest. Other studies by Malcolm (1991) found that this species was not able to cross deforested areas. However, Pires et al. (2002), in Atlantic Forest fragments, recorded the movement of one individual from one fragment to another through a matrix of tall grass.

Glironia venusta is considered a rare species and few specimens exist in collections (Emmons and Feer, 1997). Despite this, it occupies many habitat types, including open forest until Chaco, tropical humid forest, and dry forest (Tarifa and Anderson, 1997), as well as urban areas close to secondary forest (Da Silva and Langguth, 1989). This is the first record of the species in the Paraguay basin in the state of Mato Grosso, Brazil; all other records lie in the Amazon basin. Although the captured Glironia venusta had been in the interior of the fragment, the trap was placed close to a tree gap, at a height lower than $1.5 \mathrm{~m}$. Indicating that, despite being rare, the species does not require primary habitats as pointed by Da Silva and Langguth (1989).

Our categorization of some species as specialists may be confounded with capture rates. Some species we identify as specialists may not actually be restricted by 
habitat type, as for example, Didelphis marsupialis. This species classified as specialist was captured few times in our study, but other studies with a congenus species D. aurita, with higher capture rates found these species in altered areas, such as forest edges (Graipel and Santos-Filho, 2006).

The greater abundance of small mammals on transects 100 and $200 \mathrm{~m}$ from fragment edges may indicate that edge effects present a barrier to some species and limit their dispersal. Stevens and Husband (1998) captured 671 individuals of small mammals in Atlantic Forest fragments and only 43 along edges. Different from our results, some authors find higher species richness and abundance of small mammals in areas influenced by edge effects, due to individuals from adjacent secondary habitats invading fragments (Malcolm, 1997; Tattersall et al. 2002; Pardini, 2004). This effect is greater in small rather than large fragments (Malcolm, 1995; 1997; Passamani, 2003).

In this study, species richness was significantly lower in the matrix, which may be related to the simple structure of the habitat. Contrary to secondary growth areas, the pasture matrix loses a much higher number of species (Laurance and Delamônica, 1998; Bierregaard et al., 1992; Laurance, 2001). Vegetation structure and complexity are important in supplying resources such as food, nesting site, shelter, and other dimensions of a species' ecological niche, each one of fundamental importance to an individual's ability to occupy an area (Alho, 1981; August, 1983).

There was no significant difference in species richness between transects sampled in the fragments, but the majority of the areas had an increase of species in the last transects. Despite this increase, the majority of the species were not exclusive to the interior of the fragments. The use of non-favorable environments by some species may be related to the search for food resources or competition avoidance (Alho, 1981), but possibly they depend on areas considered optimal for local persistence.

In this study the pasture matrix had a significantly lower species richness and fewer individuals than transects in the fragments, suggesting that pastures have little permeability for the majority of the species (Gascon et al., 1999). According to Malcolm (1991 and 1997), few species and a limited number of individuals are able to use this type of habitat. Matrix quality, such as the type of grass planted in pastures and grazing intensity, is an important factor affecting small mammal habitat use and mobility (Pardini, 2004). The persistence of many species in fragmented landscapes depends on the quality of the matrix habitat for gene flow and re-colonization in cases of local extinctions (Turner, 1996).

Acknowledgements - We would like to thank CAPES for financing the doctoral studies of M. dos Santos-Filho. The National Institute for Amazonian Research (Instituto Nacional de Pesquisa da Amazônia - INPA) provided invaluable infrastructure and logistical support. We thank IBAMA for licenses 033/02, 004/03 and 057/04. Catherine L. Bechtoldt translated this text. We are also grateful to the farmers of our study sites in Mato Grosso, Brazil, for providing access to their land.

\section{References}

ALHO, CJR., 1981. Small mammal populations of Brazilian cerrado: the dependence of abundance and diversity on habitat complexity. Rev. Bras. Biol. = Braz. J. Biol., vol. 41, no. 1, p. 223-230.

AMARAL, DL. and FONZAR, BC., 1982. Levantamento de Recursos Naturais. In RADAMBRASIL - Folha SD 21. Cuiabá; Rio de Janeiro: MME.

ANDREWS, A. 1990. Fragmentation of habitat by roads and utility corridors: A review. Aust. Zool., vol. 26, no. 3-4, p. 130-141.

AUGUST, PV., 1983. The role of habitat complexity and heterogeneity in structuring tropical mammal communities. Ecology, vol. 64, p. 1495-1507

BIERREGAARD Jr, RO., LOVEJOY, TE., KAPOS, V., DOS SANTOS, AA. and HUTCHINGS, RW., 1992. The Biological Dynamics of Tropical Rainforest Fragments. BioScience, vol. 42, no. 11, p. $859-866$.

CÁCERES, NC. and MONTEIRO-FILHO, ELA., 1997. Reprodutive biology of the common opossum, Didelphis marsupialis (Mammalia, Marsupialia), in southern Brazil. Brenesia, vol. 47-48, p. 117-124

CÁCERES, NC. and MONTEIRO-FILHO, ELA., 1998. Population dynamics of the common opossum, Didelphis marsupialis (Mammalia, Marsupialia), in southern Brazil. Z. Säugetierk, vol. 63, p. 169-172

-, 2000. The common opossum, Didelphis aurita, as a seed disperser of several plants in southern Brazil. Ciência e Cultura, vol. 52, p. 41-44.

Da SILVA, MNF. and LANGGUTH, A., 1989. A new record of Glironia venusta from the lower Amazon, Brazil. J. Mammal., vol. 70 , no. 4 , p. 873-875.

EMMONS, LH. and FEER, F., 1997. Neotropical rainforest mammals: a field guide. 2 ed. Chicago: University of Chicago Press. 307 p.

FERNANDEZ, FAS., PIRES, AS., FREITAS, D., ROCHA, FS. and QUENTAL, TB., 1998. Resposta de pequenos mamíferos à fragmentação de habitat em remanescentes de Mata Atlântica. In Anais do IV Simpósio de Ecossistemas Brasileiros. Águas de Lindóia. São Paulo: Academia de Ciências do Estado de São Paulo, 1998, vol. V, Aciesp no 104.

FIGUEIREDO, MSL. and FERNANDEZ, FAS., 2004. Contrasting effects of fire on populations of two small rodent species in fragments of Atlantic Forest in Brazil. J. Trop. Ecol., vol. 20 , p. 225-228.

GASCON, C., LOVEJOY, TE., BIERREGAARD Jr., RO., MALCOLM, JR., STOUFFER, PC., VASCONCELOS, HL., LAURANCE, WF., ZIMMERMAN, B., TOCHER, M. and BORGES, S., 1999. Matrix habitat and especies richness in tropical forest remnants. Biol Conserv., vol. 91, p. 223-229

GRAIPEL, ME. and SANTOS-FILHO, M., 2006. Biologia de Didelphis aurita Wied-Neuwied (Didelphimorphia: Mammalia) em ambiente periurbano na Ilha de Santa Catarina, sul do Brasil. Biotemas, vol. 19, no. 1, p.65-73.

HABTEC (Engenharia Sanitária e Ambiental Ltda.), 2001. Relatório de caracterização da flora - Aproveitamento Hidrelétrico de Jauru. Rio de Janeiro, RJ. 32 p. 
LAURANCE, WF., 1990. Comparative responses of five arboreal marsupials to tropical forest fragmentation. J. Mammal., vol. 71, p. 641-653

-, 1991. Edge effects in tropical forest fragments: Application of a model for the design of Nature Reserves. Biol. Conserv., vol. 57, p. 205-219.

-, 1994. Rainforest fragmentation and the structure of small mammal communities in tropical Queensland. Biol. Conserv., vol. 69 , p. 23-32

-, 2001. Projeto de Dinâmica Biológica de Fragmentos Florestais. In PRIMACK, RB. and RODRIGUES, E. Biologia da Conservação. Londrina: 328 p.

LAURANCE, WF. and DELAMÔNICA, P., 1998. Ilhas de sobrevivência na Amazônia. C. Hoje, vol. 142, no. 24, p. 26-31.

LAURANCE, WF., LAURANCE, SG., FERREIRA, LV., RANKIN-De-MERONA, JM. GASCON, C. and LOVEJOY, TE., 1997. Biomass collapse in Amazonian Forest Fragments. Science, no. 278 , p. $1117-1118$

LAURANCE, WF., LOVEJOY, TE., VASCONCELOS, HL., BRUNA, EM., DIDHAM, RK., STOUFFER, PC., GASCON, C., BIERREGAARD, RO., LAURANCE, SG. and SAMPAIO, E. 2002. Ecosystem decay of Amazonian Forest Fragments: a 22Year Investigation. Conserv. Biol. vol. 16, no. 3, p. 605-618.

LOVEJOY, TE., 1985. Forest Fragmentation in the Amazon: A case study. In MESSEL, H. The study of Populations. Austrália: Pergamon Press.

MAGNUSSON, WE., FRANCISCO, AL. and SANAIOTTI, TM., 1995. Home-range size and territoriality in Bolomys lasiurus (Rodentia: Muridae) in an Amazonian savanna. J. Trop. Ecol., vol. 11, p. 179-188.

MALCOLM, JR., 1991. The small mammals of Amazon forest fragments: Pattern and process. Gainesville, Florida: University of Florida. [Ph.D. Thesis].

-, 1995. Forest structure and the abundance and diversity of neotropical small mammals. In LOWMANT, MD. and NADKARNI, NM. (Eds.). Forest Canopies. San Diego: Academic Press. $624 \mathrm{p}$

-, 1997. Biomass and diversity of small mammals in Amazonian Forest Fragments. In LAURANCE, WF. and BIERREGAARD $\mathrm{Jr}$, RO. Tropical Forest Remnants, Ecology, Management, and conservation of Fragmented Communities. Chicago: The University of Chicago Press, p. 207-220.

MARES, MA. and ERNEST, KA., 1995. Population and community ecology of small mammals in a gallery forest of central Brazil. J. Mammal., vol. 76, no. 3, p. 750-768.

MARES, MA., BRAUN, JK. and GETTINGER, D. 1989. Observations on the distribution and ecology of the mammals of the Cerrado grasslands of central Brazil. Annals of Carnegie Museum., vol. 58, no.1, p. 1-60.

MCT / CNPq, 1985. Pesquisa Ecológica na Região do Polonoroeste. Brasília, DF. 130 p

MESQUITA, R., DELAMÔNICA, P. and LAURANCE, WF, 1999. Effects of surrounding vegetation on edge-related tree mortality in Amazonian Forest fregments. Biol. Conserv. vol. 91, p. $129-134$

OLIVEIRA, VA., AMARAL-FILHO, ZP. and VIEIRA, PC., 1982. Levantamentos de Recursos Naturais. In RADAMBRASIL - SD 21. Cuiabá; Rio de Janeiro: MME.
PARDINI, R., 2001. Pequenos mamíferos e a fragmentação da Mata Atlântica de Una, Sul da Bahia: Processos e conservação. São Paulo: Universidade de São Paulo. [Tese de Doutorado].

-, 2004. Effects of forest fragmentation on small mammals in an Atlantic Forest landscape. Biodiv. Conservn. vol. 13, p. $2567-2586$.

PASSAMANI, M., 2003. O Efeito da fragmentação da Mata Atlântica Serrana sobre a comunidade de pequenos mamíferos de Santa Teresa, Espírito Santo. Rio de Janeiro: Universidade Federal do Rio de Janeiro, RJ. 105 p. [Dissertação de Doutorado].

PIRES, AS., LIRA, PK., FERNANDEZ, FAF., SCHITTINI, GM. and OLIVEIRA, LC., 2002. Frequency of movements of small mammals among Atlantic Coastal Forest fragments in Brazil. Biol. Conserv., vol. 108, p. 229-237

RESENDE, MS., SANDANIELO, A. and COUTO, EG., 1994. Zoneamento agroecológico do sudoeste do Estado de Mato Grosso. Cuiabá: EMPAER/EMBRAPA. (Documento 4).

RITTL, CE. 1998. Efeitos da extração seletiva de madeira sobre a comunidade de pequenos mamíferos de uma floresta de terra firme na Amazônia Central. Manaus-AM: INPA. 88 p. [Dissertação de Mestrado].

RODEWALD, AD. 2003. The importance of land uses within the landscape matrix. Wild. Soc. Bull., vol. 31, no. 2, p. 586-592.

SANTOS-FILHO, M. 2000. Uso de habitat por mamíferos nãovoadores na Estação Ecológica Serra das Araras, Mato Grosso, Brasil. Manaus-AM: INPA - Instituto Nacional de Pesquisa da Amazônia. 86 p. [Dissertação de Mestrado].

SEPLAN-MT. 2004. Diagnóstico Sócio-Econômico-Ecológico do Estado de Mato Grosso. II Aproximação. Cuiabá-MT. [CD Rom].

STALLINGS, JR., 1989. Small mammal inventories in an eastern Brazilian park. Bulletin Florida State Museum. Biol. Sciences, vol. 34 , no. 4 , p. $154-200$.

STEVENS, SM. and HUSBAND, TP., 1998. The influence of edge on small mammals: evidence from Brazilian Atlantic forest fragments. Biol. Conserv., vol. 85, p. 1-8.

STOUFFER, PC. and BIERREGAARD Jr, RO., 1995. Use of Amazonian forest fragments by understory insectivorous birds. Ecology, vol. 76, no. 8, p. 2429-2445

TARIFA, T. and ANDERSON, S., 1997. Two additional records of Glironia venusta Thomas, 1912 (Marsupialia, Didelphidae) for Bolivia. Mammalia, vol. 61, no. 1, p. 111-113.

TATTERSALL, FH., MACDONALD, DW., HART, BJ., HOHNSON, P., MANLEY, W. and FEBER, R., 2002. Is habitat linearity important for small mammal communities on farmland? J. Appl. Ecol., vol. 39, p. 643-652.

TURNER, IM., 1996. Species loss in fragments of tropical rain forest: a review o the evidence. J. Appl. Ecol., vol. 33, p. 200-209.

VIEIRA, EM., 1999. Small mammal communities and fire in the Brazilian Cerrado. J. Zool., Lond., vol. 249, p. 75-81.

VIEIRA, MV., 2002. Seasonal Niche Dynamics in Coexisting Rodents of the Brazilian Cerrado. Stud. Neotrop. Fauna Environm., vol. 38, no. 1, p. 7-15.

VIEIRA, EM. and MARINHO-FILHO, J., 1998. Pre-and PostFire habitat utilization by rodents of Cerrado from Central Brazil. Biotropica, vol. 30, no. 3, p. 491-496. 